\title{
SH3 Domain-Containing Protein 19
}

National Cancer Institute

\section{Source}

National Cancer Institute. SH3 Domain-Containing Protein 19. NCI Thesaurus. Code C98007.

SH3 domain-containing protein 19 (790 aa, $\sim 87 \mathrm{kDa}$ ) is encoded by the human SH3D19 gene. This protein is involved in the regulation of membrane protein localization and receptor ectodomain shedding. 